\title{
Doxycyclin induces p53 expression in SaOs (osteosarcoma) cell line
}

\author{
Osahon OBASUYI \\ Department of Pharmaceutical Microbiology, Faculty of Pharmacy, \\ University of Benin, P.M.B 1154, Benin-City, Edo State, Nigeria. \\ E-mail: osobex@yahoo.com,osahon.obasuyi@uniben.edu,Tel: +2348078710118
}

\begin{abstract}
The p53 tumour suppressor gene plays an important role in preventing cancer development. This study determined if p53 can be induced in osteosarcoma cell line upon treatment with Doxycyline. It was demonstrated that induction of $\mathrm{p} 53$ resulted in the inhibition of the cyclin E/CDK2 complexes by the activation of p21. This mechanism could potentially therefore represent an important component of the p53 tumor suppressor pathway.
\end{abstract}

(C) 2015 International Formulae Group. All rights reserved.

Keywords: Tumor suppressor, oncogene, mdm2, cyclinE, apoptosis

\section{INTRODUCTION:}

The p53 tumour suppressor gene plays an important role in preventing cancer development and loss of p53 function, or loss of the ability to activate a p53 response, appears to be a pre-requisite for malignant progression. In both mice and humans, germ line mutations in $\mathrm{p} 53$ result in a strong predisposition to cancer (Lozano and Zambetti, 2005). The mechanisms by which p53 functions to afford us this protection appear to be related to its ability to respond to stress and contribute to either the repair of stress-induced damage or the inhibition of further proliferation of stressed cells. In this way, disparate signals that could constitute oncogenic danger - such as oxidative stress, DNA damage, hypoxia, oncogene activation or loss of normal stromal support - all lead to the induction of a p53 response (Vousden, 2002). However, the ultimate response to $\mathrm{p} 53$ can be quite different, ranging from a reversible cell cycle arrest to the induction of a number of irreversible responses, such as cell death or senescence. This dramatic distinction in the outcome of p53 activation death or survival - leads to obvious questions of how the choice of response is regulated and why p53 initiates these different responses. To some extent, the life or death of the cell is strongly influenced by the presence or absence of p53-independent death or survival signals that cooperate with the p53activated responses. Probably the best understood activity of p53 is as a transcription factor that has sequence-specific DNA-binding activity and the potential to induce the expression of a large number of genes. Although bioinformatics studies suggested that there may be $>4000$ human genes that contain p53-binding sites (Lu, 2005), direct analysis using various 
chromatin-immunoprecipitation-based techniques have more recently placed this number between 500 and 1600 genes (Wei et al., 2006; Cawley et al., 2004) - still a daunting proposition. Key to the regulation of p53 ubiquitylation is MDM2, an ubiquitin ligase that is an essential negative regulator of p53 (Vousden, 2002). The amount of MDM2 available appears to be critical in determining the outcome: mono-ubiquitylation of p53 by low levels of MDM2 allows nuclear export, whereas higher levels of MDM2 result in poly-ubiquitylation and degradation of p53 by the proteasome (Li et al., 2003). The ability of different polymorphic forms of p53 to bind MDM2 and be exported has been linked to the efficiency of apoptotic activity (Dumont et al., 2003), which suggests that the regulation of export may help balance cell cycle arrest (which appears to be primarily due to transcriptional activity of p53) with apoptosis.

This work was undertaken to determine if $\mathrm{p} 53$ is induced in $\mathrm{SaOs}$ cell line upon treatment with doxycycline and also to determine if up-regulation of $\mathrm{p} 53$ results in the activation of p21 and subsequent downregulation of cyclinE.

\section{MATERIALS AND METHODS \\ Cell treatment}

Cells were seeded in $100 \mathrm{~mm}$ dishes and grown for 24 hours to reach $20 \%$ or $30 \%$ confluence. Then, Doxycycline was added to a final concentration of $800 \mu \mathrm{M}$. Cell lines were maintained in RPMI medium supplemented with $10 \%$ fetal bovine serum and grown to about $90 \%$ confluence for 48 hours, harvested and stored at -20 .

\section{RNA extraction and reverse transcription- PCR}

RNA was extracted with RNeasy (Qiagen) with DNase treatment according to manufacturer's instructions. The integrity and quality of RNA was checked by agarose gel electrophoresis and absorbance reading at 260 $\mathrm{nm}$. The purity was also determined according to standard procedures. RT-PCR was carried out with One Step (Qiagen) using genespecific primers and programmes.

\section{Preparation of Whole Cell Lysates \\ Lysis Buffer}

(NP-40 Lysis): $150 \mathrm{mM} \mathrm{NaCl}$, $50 \mathrm{mM}$ Tris ( $\mathrm{pH} 8.0$ ), 1\% NP-40 \{containing Protease Inhibitor Cocktail (Table 1) \}.

\section{Procedure}

Cell pellets were incubated on ice with $250 \mu \mathrm{l}$ of lysis buffer for $30 \mathrm{mins}$, vortexing after every 5 mins. The solution was spun at $14,000 \mathrm{rpm}$ for $10 \mathrm{mins}$ and the supernatant transferred to a fresh tube. The total protein concentration was determined by the Bradford assay.

\section{Western Blotting}

Cell lysates were resolved by $12 \%$ SDS-PAGE and blotted on a polyvinylidene difluoride membrane, blocked and incubated with appropriate antibodies, then washed with PBS-T and incubated with horseradish peroxidase-labelled secondary antibody. Specific immunoreactive bands were detected with enhanced chemoluminiscence (Pierce).

\section{RESULTS}

The results obtained by RT-PCR showed up-regulation of p53 upon treatment with $800 \mu \mathrm{M}$ doxyxycline. No p53 expression was observed with the untreated control (Figure 1). There was no significant difference in the expression of $\beta$-actin which was used as loading control. Western blot analysis also revealed that the treated cells showed an upregulation of p53 and a corresponding upregulation of p21 and subsequent downregulation of cyclinE (Figure 2). 

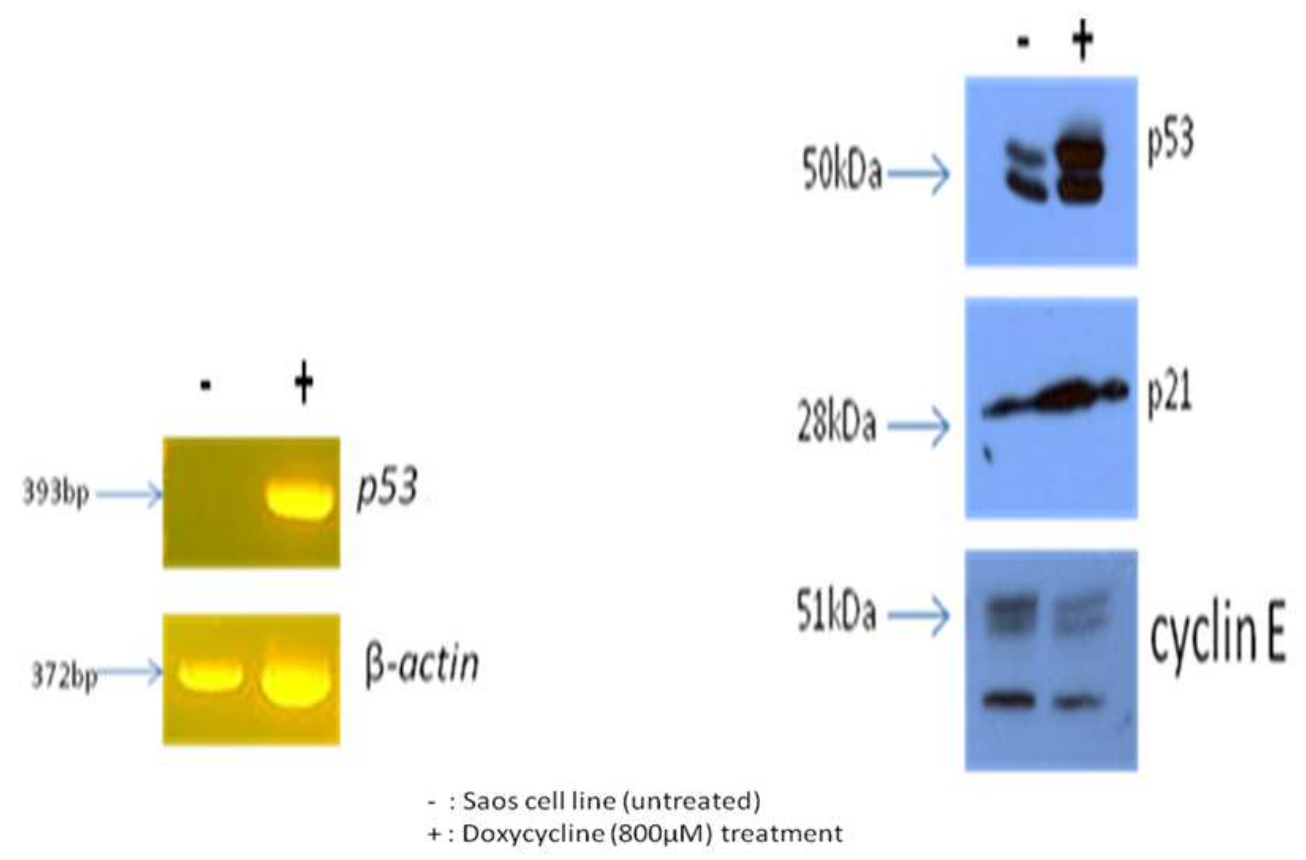

Figure 1: RT-PCR showing p53 expression in $\mathrm{SaOs}$ cell line.

Figure 2: Western blot analysis.

Table 1: Protease Inhibitor Cocktail.

\begin{tabular}{llrc}
\hline Protease Inhibitor & \multicolumn{2}{c}{ Stock Concentration } & Final Concentration \\
\hline Aprotinin & $1 \mathrm{mg} / \mathrm{ml}$ & add $5 \mu \mathrm{l} / \mathrm{ml}$ & $5 \mu \mathrm{g} / \mathrm{ml}$ \\
Leupeptin & $1 \mathrm{mg} / \mathrm{ml}$ & $5 \mu 1 / \mathrm{ml}$ & $5 \mu \mathrm{gl} / \mathrm{ml}$ \\
PMSF & $10 \mathrm{mg} / \mathrm{ml}$ & $50 \mu 1 / \mathrm{ml}$ & $500 \mu \mathrm{gl} / \mathrm{ml}$ \\
Na-ortho-vanadate & $100 \mathrm{mM}$ & $2 \mu 1 / \mathrm{ml}$ & $0.2 \mathrm{M}$ \\
$\mathrm{NaF}$ & $1 \mathrm{M}$ & $10 \mu \mathrm{l} / \mathrm{ml}$ & $0.01 \mathrm{M}$ \\
\hline
\end{tabular}

\section{DISCUSSION}

In this report, it was demonstrated that induction of p53 can result in inhibition of the cyclin E/CDK2 complexes by activation of p21. Cyclins have previously been found to be an indirect target of p53. For example, the p53-inducible protein PC3 was shown to repress cyclin D transcription in NIH 3T3 cells (Guardavaccaro et al., 2000). Inhibition of cyclin $\mathrm{E}$ level is consistent with the tumor suppressor activity of p53 since both are proto-oncogenes. Cyclin $\mathrm{E}$ functions in the
mid-G1 phase of the cell cycle where, in conjunction with its cyclin-dependent kinase partner CDK2, it acts to inhibit the retinoblastoma tumor suppressor (Harbour and Dean, 2000). Consistent with this proliferative function, cyclins are found to be over-expressed in most human breast cancers (Weinstat-Saslow et al., 1995). Our results indicate that Doxycycline treatment of $\mathrm{SaOs}$ cell line induces the expression of p53 leading to the activation of p21 and subsequent downregulation of cyclinE. This mechanism could 
potentially therefore represent an important component of the p53 tumor suppressor pathway.

\section{REFERENCES}

Cawley S, Bekranov S, Kapranov P, Sekinger EA, Kampa D, Piccolboni A, Sementchenko V, Cheng J, Williams AJ, Wheeler R, Wong B, Drenkow J,Yamanaka M, Patel S, Brubaker S, Tammana H, Helt $\quad$ G, Struhl K, Gingeras TR. 2004. Unbiased mapping of transcription factor binding sites along human chromosomes 21 and 22 points to widespread regulation of non-coding RNAs. Cell, 116: 499-509.

Dumont P, Leu JI, Della Pietra AC, George DL, Murphy MP. 2003. The codon 72 polymorphic variants of p53 have markedly different apoptotic potential. Nat. Genet., 33: 357-365.

Guardavaccaro D, Corrente G, Covone F, Micheli L, D'Agnano I, Starace G Caruso M, Tirone F. 2000. Arrest of G1-S progression by the p53-inducible gene $\mathrm{PC} 3$ is $\mathrm{Rb}$ dependent and relies on the inhibition of cyclin D1 transcription. Mol. Cell. Biol., 20: 1797-1815.

Harbour JW, Dean DC. 2000. The Rb/E2F pathway: expanding roles and emerging paradigms. Genes Dev., 14: 2393-2409.
Li M, Brooks CL, Wu-Baer F, Chen D, Baer $\mathrm{R}, \mathrm{Gu} \quad \mathrm{W} .2003$. Mono-versus polyubiquitination: differential control of p53 fate by Mdm2. Science, 302: 19721975.

Lozano G, Zambetti GP. 2005. What have animal models taught us about the p53 pathway? J. Pathol., 205: 206-220.

$\mathrm{Lu}$ X. 2005. p53: a heavily dictated dictator of life and death. Curr. Opin. Genet. Dev., 15: 27-33.

Vousden KH. 2002. Activation of the p53 tumor suppressor gene. Biochem. Biophys. Acta, 1602: 47-59.

Wei CL, Wu Q, Vega VB, Chiu KP, Ng P, Zhang T, Shahab A, Yong HC, Fu Y, Weng Z. Liu J, Zhao XD, Chew J, Lee YL, Kuznetsov VA, Sung W, Miller LD, Lim B, Liu ET, Yu Q, Ng H, Ruan R. 2006. A global map of p53 transcription-factor binding sites in the human genome. Cell, 124: 207-219.

Weinstat-Saslow D, Merino MJ, Manrow RE, Lawrence JA, Bluth RF, Wittenbel KD, Simpson JF, Page DL, Steeg PS. 1995. Over-expression of cyclin D mRNA distinguishes invasive and in situ breast carcinomas from non-malignant lesions. Nat. Med., 1: 1257-1260. 